\title{
Antiguidade e modernidade na Teoria do romance de Georg Lukács
}

\author{
Antiquity and Modernity in The Theory of the Novel by Georg Lukács
}

\author{
Anouch Neves de Oliveira Kurkdjian* \\ anouch.kurkdjian@usp.br \\ (Universidade de São Paulo, São Paulo, Brasil)
}

\begin{abstract}
Resumo: Este artigo orienta-se pelo esforço de esmiuçar as características da contraposição entre mundo antigo e mundo moderno formulada por Lukács em sua obra $A$ teoria do romance. Para esse objetivo, parte-se de uma recuperação de certo debate estético alemão no século XVIII, momento no qual a busca pelos fundamentos da arte moderna leva à formulação do contraste entre uma cultura orgânica e plena de sentido, localizada em uma Grécia mítica, e um mundo cindido e fragmentado, que corresponderia à época moderna. As reflexões de Friedrich Schlegel ganham atenção especial aqui, na medida em que tratam essa contraposição de maneira mais histórica do que as de seus contemporâneos. Em seguida, são apontadas as especificidades da abordagem de Lukács acerca da questão, baseadas em uma apreensão mais atenta aos fundamentos histórico-sociais que envolvem a perda de um sentido unitário para a vida na modernidade. Essa percepção permite a Lukács apontar os limites da solução aventada pelos românticos para a superação do caráter cindido da modernidade.
\end{abstract}

Palavras chaves: romance; utopia; mundo da arte; mundo da vida.

\begin{abstract}
This article aims to illuminate the contrast between ancient and modern world formulated by Lukács in his work The Theory of the Novel. In order to do this, we turn back to a debate on Aesthetics from the XVIII century Germany, where the search for the fundamentals of modern art leads the debate to the construction of a contrast between an organic culture, filled with meaning, located in a mythical conception of Greece, and a splitted and fragmented world, which corresponds to the modern era. Friedrich Schlegel's reflections on this subject are taken into special account here, since he treated this comparison in a historical way more so than his contemporaries. Following this, we point to the specificities of Lukács' approach to the issue, which is more attuned to the historical and social basis of the process that culminated in the loss of a unitary meaning for life in modernity. We seek to show how this perception makes possible for Lukács to point out the limits of the romantic solutions to the splitted character of modernity.
\end{abstract}

Keywords: novel; utopia; world of art; world of life.

DOI: http://dx.doi.org/10.11606/issn.2318-9800.v25i1p13-29

\section{Os dois mundos da épica}

As pedras nas entranhas da terra e os planetas nas esferas celestes se preocupavam ainda com o destino do homem, ao contrário dos dias de hoje, em que tanto no céu como na terra tudo se tornou indiferente à sorte dos seres humanos, e em que nenhuma voz, venha de onde vier, lhes dirige a palavra ou thes obedece. Os planetas recém-descobertos não desempenham mais nenhum papel no horóscopo, e existem

* A autora agradece a bolsa recebida para a realização da pesquisa de mestrado que deu origem a esse artigo científico - processo n 2012/11906-8, Fundação de Amparo à Pesquisa do Estado de São Paulo (FAPESP). 
inúmeras pedras novas, todas medidas e pesadas e com seu peso específico e sua densidade exatamente calculados, mas elas não nos anunciam nada e não tem nenhuma utilidade para nós. 0 tempo já passou em que elas conversavam com os homens.

Nikolai Leskov, “A alexandrita” (1884)

O trecho do conto "A alexandrita” de Nikolai Leskov, não por acaso retomado por Benjamin em "O narrador”, descreve uma época na qual o homem ainda podia se sentir em harmonia com a natureza, os céus ainda ofereciam alguma orientação para o percurso da humanidade e o mundo era vivido como uma totalidade. Segundo essa mesma passagem de Leskov, na época moderna, ao contrário, os seres humanos viveriam suas vidas separados da natureza, alheios a quaisquer desígnios superiores ou amparos celestes. O reino natural seria agora tão somente um objeto a ser conhecido racionalmente - medido, pesado, calculado -, mas ele não possuiria nenhum significado mais elevado, não forneceria nenhuma orientação para a ação humana.

É nesse mesmo espírito que se inicia a primeira parte de A teoria do romance, na qual Lukács insere o romance na linhagem da grande épica, concebendo-o como o desenvolvimento histórico da epopeia, ou, se quisermos, como "moderna epopeia burguesa", na clássica formulação de Hegel. ${ }^{1}$ A contraposição entre duas espécies de épica distintas sustenta-se na diferença entre dois estados de mundo, ou aos dois tipos de cultura que dão origem a cada uma dessas formas. De acordo com o argumento de Lukács, a epopeia corresponderia ao que ele denomina de "mundo fechado", ao passo que o romance seria a forma épica característica de uma "cultura problemática", não unitária. A primeira parte do ensaio é em larga medida dedicada à exposição dos traços mais determinantes desses dois universos e da relação que cada um deles mantém com a epopeia e com o romance, respectivamente.

Ecoa no livro, nesse sentido, aquela oposição, florescida no pensamento estético alemão no século XVIII, entre duas épocas: a antiguidade, harmoniosa, perfeita em si mesma e unitária, e a modernidade, fundamentalmente cindida. Quase um século

\footnotetext{
1 A caracterização do romance enquanto epopeia burguesa, embora tenha se celebrizado com Hegel, não é inaugurada por ele, mas aparece já em Friedrich von Blackenburg em seu Versuch über den Roman [Ensaio sobre o romance] (1774): "Considero o romance, o bom romance, como aquilo que, nos tempos helênicos a epopeia era para os gregos". A formulação de Hegel é a seguinte: "de uma maneira inteiramente diferente se passam as coisas com o romance, a moderna epopeia burguesa. Aqui intervém novamente, de um lado, de modo pleno, a riqueza e a variedade de interesses, de estados, de caracteres, de relações de vida, o amplo pano de fundo de um mundo total, bem como a exposição épica de eventos. 0 que falta, contudo, é o estado de mundo originariamente poético, do qual nasce a epopeia propriamente dita. 0 romance, no moderno sentido, pressupõe uma efetividade já ordenada para a prosa, sobre cujo terreno ele novamente recupera em seu círculo da poesia - tanto no que diz respeito à vitalidade dos acontecimentos quanto no que se refere aos indivíduos e seu destino -, até onde é possível nesta pressuposição, seu direito perdido" (Hegel, 2004, p.137).
} 
após a Querelle des anciens et des modernes, ${ }^{2}$ que se desenrolou na França em finais do século XVII, um prolongamento desse debate em território germânico opôs certa ortodoxia estética inspirada no neoclassicismo francês e os partidários de um pensamento que, se em alguns casos ainda defendia valores clássicos para as artes, opunha-se, entretanto, à imitação de modelos importados da França. Assim, de um lado, estavam os partidários daquele neoclassicismo de inspiração teórica e prática francesa, para o qual Boileau ${ }^{3}$ e Racine figuravam como as autoridades máximas, exemplos a serem seguidos pelos artistas alemães que, segundo essa perspectiva, não contavam com uma tradição artística nacional digna de ser considerada canônica e modelar. ${ }^{4}$ De outro, a tentativa de Baumgarten de fundar uma nova ciência estética (Aesthetica, 1750), o tratado de Lessing sobre as diferenças entre as artes visuais e as poéticas (Laocoon, 1766) e os programas de refundação do classicismo helênico de Winckelmann, Goethe e Schiller dão testemunho do processo de superação dessa dependência francesa e da fundação de uma reflexão crítica alemã que, sustentada por conhecimentos históricos, busca em um passado mais longínquo, isto é, na própria Grécia antiga, as bases para a arte alemã da época.

Foi no contexto dessa disputa que surgiu o interesse pelo estudo aprofundado - podemos mesmo dizer, propriamente histórico - da arte grega no pensamento alemão. A figura de Winckelmann aparece como inauguradora desse processo, uma vez que ele foi uma espécie de "descobridor" da cultura grega: seu livro Reflexões sobre a imitação das obras gregas na pintura e na escultura (1755) foi a primeira tentativa de compreender a arte e a cultura gregas a partir da investigação de sua gênese histórica, mobilizando para isso fontes da própria cultura grega e não recorrendo à interpretação dos gregos feita pela cultura romana, como era o usual naquela época. Com Winckelmann, portanto, a arte grega passa a ser remetida a seu contexto, sendo concebida como a manifestação cultural de um povo e, logo, como uma expressão artística geográfica e historicamente situada. Além disso, o estudo de Winckelmann também foi responsável por delinear os contornos do que viria a se

2 É no âmbito desse debate estético que surge pela primeira vez a consciência do presente como uma época qualitativamente distinta da que o antecedeu, por oposição à ideia de um desenrolar do tempo como continuidade homogênea. À ideia da modernidade como uma "nova época", associase o problema da fundamentação dessa época a partir de si mesma. 0 despontar dessa consciência histórica conduz ao questionamento, no campo artístico, da antiga relação de dependência da modernidade frente à antiguidade: a validez atemporal da arte clássica - antes tida como modelo a ser imitado pela arte de épocas posteriores - é posta em xeque pela defesa da superioridade da arte moderna feita pelo partido dos modernos, representados na Querelle por Charles Perrault. Cf. Habermas, 2002, pp.3-18. Sobre a Querelle, cf. Fumaroli, 2001, pp.7-220; Armogathe, 2001, pp.801-849.

$3 \mathrm{Na}$ Querelle, Nicolas Boileau-Despréaux posicionava-se como defensor intransigente da arte clássica, donde seu epíteto "legislador do Parnasso".

4 Vale lembrar que a questão da ausência de uma tradição literária nacional estava conectada à ausência uma unidade nacional alemã. Essa questão da "falta" estará no horizonte dos empreendimentos artísticos alemães e afetará o curso de seu desenvolvimento. Cf. Reed e Pasley, 1982, pp.499-558. 
tornar um mito recorrente e central para a cultura alemã: o ideal de helenidade e da perfeição artística clássica.

A caracterização do mundo grego feita por Lukács é claramente inspirada nesse ideal erigido por Winckelmann, ${ }^{5}$ o que fica patente na bela passagem de abertura da Teoria do romance:

Afortunados os tempos para os quais o céu estrelado é o mapa dos caminhos transitáveis e a serem transitados, e cujos rumos a luz das estrelas ilumina. Tudo thes é novo e no entanto familiar, aventuroso e no entanto próprio. 0 mundo é vasto, e no entanto é como a própria casa, pois o fogo que arde na alma é da mesma essência que as estrelas; distinguem-se eles nitidamente, o mundo e o eu, a luz e o fogo, porém jamais se tornarão para sempre alheios um ao outro, pois o fogo é a alma de toda luz e de luz veste-se todo fogo (Lukács, 2000, p.25).

A prosperidade dos tempos clássicos advém do fato de que neles o eu e o mundo formam uma totalidade imediatamente dotada de sentido. Trata-se de um mundo homogêneo, uma estrutura circular cujos contornos são bem definidos e cujas partes estão organicamente relacionadas; aí, os homens não são uma parte autônoma da totalidade social, mas a compõem organicamente. Dentro dessa totalidade está um mundo perfeito e acabado, pleno de sentido.

Talvez mais importante do que a apresentação positiva do mundo grego no ensaio de Lukács, seja sua caracterização como contraponto, que já oferece a fisionomia do que seria o mundo moderno: no mundo harmônico grego não há alheamento entre eu e mundo, nem cisão entre interioridade e exterioridade. A orientação para a conduta dos homens lhes é dada imediatamente - "toda ação é somente um traje bem-talhado da alma" (idem, p.26). Nesse mundo afortunado, não poderia nem mesmo existir a interioridade, uma vez que não existe ainda o exterior, o outro da alma. Os deuses controlam esse mundo, mas não estão afastados dos homens; ao contrário, convivem com eles e os guiam em suas aventuras, tal como "o pai diante do filho pequeno" (idem, ibidem). Anuncia-se, assim, o mundo moderno como uma antítese da era de Homero: enquanto esta é apresentada como um universo pleno de sentido, aquele se caracteriza pela cisão entre empiria e essência, pela perda de todo e qualquer sentido imediatamente dado.

\footnotetext{
5 A imagem que Winckelmann constrói da Grécia a partir de seus estudos a respeito da arte antiga é de uma cultura orgânica, coerente, um ideal não apenas estético, mas também moral, político e espiritual. A partir da análise do conjunto estatutário do Laocoonte, Winckelmann formula a peculiaridade da arte grega da seguinte maneira: "Enfim, o traço geral preponderante das obras-primas gregas é uma nobre simplicidade e uma calma grandeza, tanto na postura quanto na expressão. Assim como a profundeza do mar permanece tranquila, por mais tempestuosa que esteja a superfície, a expressão nas figuras dos gregos mostra, em meio a todas as paixões, uma alma grande e comedida" (Winckelmann, 1954, p.142). Essa caracterização aponta não apenas para atributos estéticos da arte grega, mas também para um ideal de humanidade nela presente, uma vez que Winckelmann enfatiza as qualidades morais do herói grego Laocoonte - sua compostura espiritual, sua superioridade mesmo em face dos maiores desafios e turbulências. Além disso, há a valorização da simplicidade como um atributo ético, mais do que simplesmente artístico: a arte grega é uma arte do essencial, do universal, e não do ornamento e do rebuscado. Cf., nesse sentido, Nisbet, 1985; Süssekind, 2008.
} 


\section{Cultura clássica e cultura moderna em Friedrich Schlegel e Lukács}

A percepção de uma ruptura entre época moderna e época clássica constitui também o solo no qual se desenvolve a teoria estética do primeiro romantismo; tanto as temáticas discutidas por seus autores, quanto os conceitos por eles mobilizados são profundamente impactados pela consciência da diferença fundamental entre as duas épocas. Inspirado em Winckelmann, Friedrich Schlegel, no ensaio Sobre o estudo da poesia grega, escrito em 1795, procura compreender a gênese da literatura grega a partir de suas relações com a estrutura da cultura clássica e, nesse percurso, acaba por elaborar também uma teoria da literatura moderna. Em linhas gerais, a obra contrapõe o caráter natural da cultura antiga ao caráter artificial da cultura moderna e sua poesia, determinadas pela razão. A cultura clássica é apresentada por Schlegel, à maneira de Winckelmann, como um momento no qual a beleza crescia sem cuidado artificial, pois era uma qualidade inata. As artes plásticas, por exemplo, não eram atividades proveniente de uma capacidade aprendida dos gregos, mas simplesmente a manifestação de sua natureza originária:

$\mathrm{Na}$ Grécia crescia a beleza sem o cuidado artificial e quase como selvagem. Sob esse céu feliz a arte plástica não era uma capacidade aprendida, mas natureza originária. Sua formação não era senão o desenvolvimento mais livre da índole mais afortunada (Schlegel, 1996, p.97).

Asimplicidade da cultura grega, contudo, não é vista sob a ótica da insuficiência, mas precisamente como um trunfo, pois atestaria o caráter incorrupto dessa cultura, na qual nenhum princípio externo se impõe frente ao livre desenvolvimento de sua natureza. Enquanto a formação grega é entendida como uma natureza orgânica, a cultura moderna é um ser artificial, criado. A unidade da cultura grega é, portanto, diferente da moderna: enquanto lá a unidade é orgânica e natural, a cultura moderna é uma unidade criada, artificialmente composta. Na antiguidade, a cultura desenvolviase naturalmente, ao passo que na modernidade ela é regida pelo entendimento: ${ }^{6}$

\footnotetext{
6 Pouco depois da redação do ensaio de Schlegel, Friedrich Schiller publica seu escrito Sobre a poesia ingênua e sentimental, no qual a relação entre a naturalidade e a artificialidade na literatura também é um tema central. De maneira bastante breve, poderíamos conceitualizar o "ingênuo" como a relação imediata com a natureza, ao passo que o "sentimental" é a busca por retornar a essa condição após a entrada na artificialidade; a atitude sentimental, portanto, também em Schiller, está pautada pela reflexão e pelo intelecto. Embora nesse sentido as proposições de Schlegel e Schiller se aproximem, alguns comentadores afirmam que enquanto a abordagem de Schlegel sustenta-se em um pensamento radicalmente histórico, o mesmo não ocorreria em Schiller, cuja perspectiva se manteria em um terreno ahistórico, pois seus conceitos de ingênuo e sentimental não diriam exatamente respeito a duas épocas históricas, antiguidade e modernidade, mas a duas atitudes criativas. Prova disso seria o fato de que Schiller classifica alguns poetas modernos como ingênuos; esse é o caso de Goethe, por exemplo.Cf. D'Angelo, 1998, p.45. Uma interpretação alternativa e mais matizada pode ser encontrada em Szondi, 1975b.
} 
O entendimento dissociador começa separando e individualizando o todo da natureza. Sob sua direção avança a exclusiva orientação da arte no sentido da fiel imitação do individual. Assim, pois, em uma cultura intelectual superior, a individualidade original e interessante se converteu na meta da literatura moderna (idem, p.77). ${ }^{7}$

Historicamente, a artificialidade da época moderna teria em Dante seu primeiro representante. Numa análise da Divina comédia - amplamente retomada por Lukács na Teoria do romance, vale ressaltar - Schlegel compara a forma do poema épico de Dante com a totalidade da epopeia homérica. Mas, para Schlegel, o espírito moderno encontraria sua expressão mais cristalina na obra de Shakespeare, especialmente em Hamlet. Nessa obra, não é o belo que determina o todo: este antes serve ao interesse característico ou filosófico. Além disso, sua representação não é objetiva, mas completamente maneirista. Mais importante ainda para a caracterização do caráter cindido da cultura moderna é a figura do protagonista, na medida em que este é o maior representante das qualidades próprias ao novo homem da época:

Devido a uma situação maravilhosa, toda a força de sua nobre natureza é comprimida em seu entendimento, mas sua força ativa é totalmente aniquilada. Seu espírito se separa em direções contrárias, despedaçado como num banco de tortura; se decompõe e sucumbe ao excesso de um entendimento inativo que o oprime mais dolorosamente que todos os que dele se aproximam. Não há talvez representação mais perfeita da desarmonia insolúvel, que é o verdadeiro objeto da tragédia filosófica, que uma desproporção tão sem limites entre a força pensante e a ativa como no caráter de Hamlet (idem, p.78).

A cisão entre pensamento e ação, o predomínio do entendimento sobre o ser, enfim, o isolamento do sujeito, separado do mundo, tudo se encontra tematizado em Hamlet, obra que não representa mais a harmonia suprema entre homem e destino, como nas tragédias clássicas, mas tem como problema central justamente a desarmonia entre ser e destino própria à modernidade.

No plano artístico, a diferença entre a coesão estruturante da época clássica e o fundamento fragmentário da época moderna determina que os valores pelos quais a poesia moderna se orienta sejam distintos daqueles perseguidos pela poesia clássica. Enquanto esta tem o belo como valor último, a ser atingido por meio da objetividade, a literatura moderna se orienta pelo interessante, uma força estética subjetiva, voltada ao interesse particular, ao assunto individual. Embora Schlegel reconheça que a poesia moderna oferece um grande número de obras capazes de suscitar emoções poderosas, o prazer por elas proporcionado não é completo, pois falta-lhes a plenitude que garante a satisfação: elas oferecem uma quantidade de belezas isoladas, mas não a harmonia e a perfeição.

7 Sobre o conceito de interessante na obra de Schlegel, ver Silva, 2011, pp.75-94. 
Quase em toda parte, tacitamente pressuposto ou expressamente estabelecido, encontrareis antes qualquer outro princípio como a mais alta meta e a primeira lei da arte, como última norma do valor de suas obras; mas não o belo. O belo é tão pouco dominante na poesia moderna, que muitas das melhores obras desta são evidentemente representações do feio; e ao fim, haverá de confessar, mesmo que com desgosto, que há uma representação da confusão em seu mais alto grau, do desespero em toda sua abundância, que exige a mesma - se não uma mais alta força criadora e sabedoria artística que a representação da plenitude e da força em perfeita harmonia (idem, pp.60-61).

É interessante observar como Schlegel, apesar de examinar o moderno a partir do confronto deste com o antigo e apesar de qualificar a arte grega como a mais nobre da história, já não atribui a ela a função de modelo para a arte moderna, como ocorria em Winckelmann. Embora valorize o caráter natural da cultura grega, Schlegel reconhece também que a artificialidade moderna implica uma maior liberdade frente à natureza. A história natural da antiguidade é substituída por uma história da subjetividade, pela história da cultura moderna, e a consideração detalhada da literatura moderna e de suas peculiaridades impede que ela seja julgada pelos mesmos critérios a partir dos quais se avaliava a literatura clássica.

Antiguidade e modernidade, portanto, não são mais concebidas como etapas de uma mesma linha de evolução, mas como culturas de naturezas distintas. Em Schlegel, a cultura clássica converte-se na contra-imagem que, embora sirva de medida para a avaliação da modernidade, não mais funciona como um modelo que ainda possa ser imitado. ${ }^{8} \mathrm{~A}$ imagem mítica dos gregos cumpre a função de ser um contraponto de sua época, servindo-lhe menos como um modelo e mais como apoio para uma crítica de seu presente. Desse modo, é possível notar que, inspirado pelas caracterizações de Winckelmann, Schlegel dá um passo além de seus precursores ao avançar para uma interpretação inaugural de sua própria época: a partir do traço já evocado por outros antes dele - o da naturalidade da cultura grega -, Schlegel confere um novo estatuto à artificialidade da cultura moderna, radicalizando o afastamento entre modernidade e antiguidade clássica.

Voltemos à Teoria do romance para vermos mais de perto como Lukács lança mão dessa contraposição entre antigos e modernos. Aprofundando sua caracterização da cultura grega, ele afirma:

Se quisermos, assim podemos abordar aqui o segredo do helenismo, sua perfeição que nos parece impensável e a sua estranheza intransponível para nós: o grego conhece somente respostas, mas nenhuma pergunta, somente soluções (mesmo que enigmáticas), mas nenhum enigma, somente formas, mas nenhum caos (Lukács, 2000, p.27).

8 É o que sustentam Peter Szondi (1992) e D’Angelo (1998). 
Em "A metafísica da tragédia”, ensaio sobre Paul Ernst que compõe o livro $A$ alma e as formas, encontramos uma das formulações mais claras a respeito do par conceitual "forma" e "vida”. Nesse texto, Lukács descreve a vida como

uma anarquia de luz e escuro: nada jamais é completamente realizado na vida, nada jamais acaba inteiramente; novas vozes confusas sempre se misturam ao coro daqueles que foram ouvidos antes. Tudo flui, tudo se funde em outra coisa, e a mistura é descontrolada e impura; tudo é destruído, tudo é esmagado, nada jamais floresce em vida verdadeira (Lukács, 2010b, p.176).

Assim, põe-se a questão de como uma estrutura de sentido, uma vida verdadeira, pode emergir desse caos que é a vida empírica. A resposta para Lukács está na forma: "a forma é o maior juiz da vida. A formalização é uma força julgadora, uma ética; existe um julgamento de valor em tudo a que foi dado forma. Todo tipo de formalização, toda forma literária, é um degrau na hierarquia de possibilidades de vida" (idem, p.197).

Ora, a forma, portanto, funciona como uma espécie de filtro que permite configurar a vivência - que em si é um fluxo caótico de eventos - e conferir um sentido a ela. Por meio da ordenação de um todo antes indistinto, o que por sua vez pressupõe um julgamento ético do que é significativo e do que não é, a forma atribui um sentido à desordem da vida. Mas, se o mundo da epopeia caracteriza-se pela harmonia orgânica entre suas partes e pela presença de um sentido imanente à vida, a forma possui aí um sentido particular: em uma situação de mundo na qual a experiência não é um todo desordenado, a epopeia apenas traz à tona o sentido já presente no mundo; ela é somente a expressão de um mundo já configurado previamente. No mundo homérico, portanto, não existe uma dualidade entre vida e forma. Não por outro motivo, segundo Lukács, nesse universo "saber é apenas alçar véus opacos; criar, apenas copiar essencialidades visíveis e eternas; virtude, um conhecimento perfeito dos caminhos" (Lukács, 2000, p.29). Em mundo fechado, claramente ordenado, as formas apenas incorporam o sentido que thes é oferecido imediatamente, de maneira que elas mesmas possuem uma existência que poderíamos chamar de natural ou ao menos óbvia, sendo perfeitas e bem acabadas tal como seu mundo.

Isso é abordado a partir da ideia de "topografia transcendental do espírito grego", que indica a relação entre vida e substância em cada etapa da história grega. Lukács distingue no processo de evasão do sentido no mundo três fases que se expressam nas três "grandes formas intemporalmente paradigmáticas da configuração do mundo": epopeia, tragédia e filosofia. ${ }^{9}$ No mundo da epopeia, a substância ainda

\footnotetext{
9 Mas, como afirma o tradutor da Teoria do romance: "Há de ficar claro que, no mundo grego, a substância está sempre presente, não importa em qual de seus estágios, seja épica, tragédia ou filosofia; o que se altera é a relação com essa substância - da imanência à vida até a transcendência - de Homero à Platão" (Nota do tradutor. In: Lukács, 2000, p.33).
} 
é absolutamente imanente à vida, enquanto no estágio da tragédia a vida empírica perde a imanência da essência, mas o momento trágico ainda consegue engendrar a essência na vida empírica. Já com a filosofia, a essência se torna a única realidade transcendente, e a vida empírica é finalmente preterida. O caráter fechado do mundo homérico, portanto, sofre uma progressiva dissolução até romper-se de vez na época moderna. Trata-se aqui, no fundo, de apontar a passagem de uma situação na qual as diferentes esferas da vida compunham uma unidade - "quando saber é virtude e a virtude, felicidade; quando a beleza põe em evidência o sentido do mundo" (idem, p.31) - para uma nova situação, de relativa autonomia dessas esferas de valor.

É impossível não pensar, nesse ponto, na tese weberiana da modernização cultural como progressiva diferenciação, autonomização e institucionalização das ordens de vida [Lebensordnungen], que passam a obedecer a uma racionalidade interna. Esse processo é exposto com bastante clareza no famoso texto "Consideração intermediária”, a respeito do qual Antonio Flávio Pierucci comenta:

O desencantamento do mundo pelo monoteísmo ético atravessa como um vetor o Ocidente no bojo da milenar dominância cultural de uma imagem de mundo metafísico-religiosa crescentemente unificada e internamente sistematizada, que terminou por se impor como fundamento legítimo da ordem social como um todo. Com o advento da modernidade e a ruptura dos laços tradicionais por uma série de fatores, inclusive no plano cultural e no da personalidade, Weber diagnostica uma importante inflexão no processo de racionalização ocidental: agora é possível conceber a esfera doméstica e a economia, a política e o direito, a vida intelectual e a ciência, a arte e a erótica, independentemente das fundamentações axiológicas religiosas (Pierucci, 2003, p.138).

Nesse novo contexto, a arte não é a mais a exposição sensível de um sentido previamente existente, mas passa a ser ela mesma a criação de um sentido. É como se, da Grécia homérica ao mundo contemporâneo, a relação entre ética e estética tivesse se invertido. Lá, a ética está dada e a estética apenas a reproduz: "as formas não são uma coerção, mas somente a conscientização, a vinda à tona de tudo quanto dormitava como vaga aspiração no interior daquilo a que se devia dar forma" (Lukács, 2000, p.31). Mas com a perda da imanência do sentido à vida e com a derrocada da ética como parâmetro universal para a conduta, a estética passa a anteceder a ética e deve, ela mesma, assumir a tarefa de configurar um sentido. Trata-se, sem dúvida, de uma tarefa mais árdua do que antigamente, pois aqui as formas "têm de produzir tudo o que até então era um dado simplesmente aceito” (idem, p.36).

Assim, na modernidade, as formas clássicas, perfeitas e acabadas, perdem seu apelo inevitável e a adesão imediata a elas dá lugar à criação de novas formas pela subjetividade do artista. A arte torna-se, assim, “independente: ela não é mais uma cópia, pois todos os modelos desapareceram; é uma totalidade criada, pois a unidade natural das esferas metafísicas foi rompida para sempre” (Lukács, 2000, p.34). Isso 
não significa que a arte esteja, a partir de então, completamente desvinculada da realidade, mas que ela constitui-se como uma esfera particular da atividade humana, como uma maneira específica de conhecer e configurar o mundo, não mais submetida a fins religiosos. A autonomia da arte, sua constituição enquanto uma área autônoma frente à moralidade comunitária ou à verdade religiosa, é concebida, portanto, como o resultado de um processo histórico-social que dissolveu o antigo sentido unitário do mundo.

Esse reconhecimento de que a arte torna-se, na modernidade, uma esfera autônoma, que obedece às suas próprias leis e não está mais vinculada a um sentido prévio oferecido pela religião ou por valores comunitários - ou seja, um reconhecimento que passa por uma teoria da modernização, entendida como um processo social objetivo - parece ser um traço que distingue a abordagem de Lukács tanto dos diagnósticos quanto, principalmente, das soluções aventadas por Friedrich Schlegel para os problemas da cultura moderna.

Para compreendermos melhor essa diferença, é preciso atentar para um outro aspecto da teoria romântica, sua filosofia da história. ${ }^{10}$ Peter Szondi chama a atenção para o fato de que a peculiaridade da filosofia da história do romantismo, que the permite inclusive ser entendida como uma filosofia moderna da história, é que o presente é sempre caracterizado como um tempo intermediário, provisório, um "não mais" e um "ainda não". Nesse sentido, o presente é uma espécie de antítese que se estabelece em relação a uma tese, localizada no passado, e a expectativa de uma síntese no futuro (Szondi, 1975a, p.96). A filosofia da história de Schlegel se estruturaria, de acordo com essa visão, em três momentos: o passado harmônico da antiguidade, o presente cindido da modernidade e a esperança de uma reconciliação no futuro.

Tanto em Sobre o estudo da poesia grega, quanto nos fragmentos das revistas Lyceum (estes também chamados de Fragmentos críticos) e Athenäum (1798-1800), é possível perceber que Schlegel procura estabelecer não somente a gênese da poesia moderna, como se preocupa também em desvendar o futuro de sua evolução, sua meta última. Em Sobre o estudo da poesia grega, a tendência da história é exposta da seguinte maneira:

10 Lacoue-Labarthe e Nancy, em seu estudo fundamental sobre o romantismo, consideram necessário estabelecer limites históricos claros para o movimento romântico. Não se trata, por um lado, de pensar o romantismo enquanto um tipo de sensibilidade ou um estado de ânimo, aos quais o movimento acabou por ser associado retrospectivamente, nem, por outro de tomá-lo como um bloco indistinto, haja visto que sua orientação teórica e política sofreria mudanças consideráveis ao longo de seu desenvolvimento. Grande parte das interpretações sobre o romantismo teria padecido de certa negligência em localizar o movimento de modo preciso, tornando impossível diferenciar suas primeiras formulações daquelas de tons claramente mais conservadores que acompanham a conversão de Schlegel ao catolicismo e sua associação com Metternich. Como já foi dito, nos referimos ao movimento que se reuniu em Jena em torno das revistas Lyceum e Athenäum. Cf. Lacoue-Labarthe e Nancy (1988). 


\begin{abstract}
Quantas mais vezes foi decepcionado o desejo, fundado na natureza humana, de satisfação completa mediante o individual e o cambiante (para cuja descrição havia estado a arte orientada exclusivamente até agora), tanto mais veemente e incansável se fez. Só o geral, constante e necessário: o objetivo, pode preencher esse grande vazio; só o belo pode acalmar esse ardente anseio. (...) 0 excesso do individual conduz, pois, por si mesmo ao objetivo; o interessante é a preparação do belo, e o fim último da literatura moderna não pode ser outro que o sumo do belo, um máximo de perfeição estética objetiva. (...) O domínio do interessante é só uma crise passageira do gosto, pois ao final tem que destruir-se a si mesmo (Schlegel, 1996, p.81).
\end{abstract}

A situação da arte moderna não significa, portanto, um ponto final na história do desenvolvimento da cultura; trata-se antes de um período de crise passageira, cuja superação num futuro próximo se dá por uma inversão dialética: a exacerbação do individual conduz por si mesma ao objetivo; o predomínio do interessante revertese na sua própria destruição; em suma, a literatura moderna tem como fim último o belo, a perfeição estética objetiva. Para Schlegel, "a poesia de Goethe é a aurora da arte autêntica e da beleza pura" (idem, p.85), pois, em sua fase weimariana, o poeta alemão estaria "entre o interessante e o belo, entre o amaneirado e o objetivo" (idem, p.86). Goethe inauguraria, assim, uma nova etapa da cultura estética moderna, ao sintetizar elementos modernos e objetividade clássica. A formação moderna, portanto, tenderia em seu desenvolvimento à recuperação da objetividade própria à arte grega - que não é atingida pela imitação dos modernos, como em Winckelmann, mas pela mescla entre a objetividade e as características modernas. Mais especificamente, o que Schlegel afirma é que Goethe consegue conferir uma espécie de objetividade mesmo aos traços subjetivos, como a maneira. No entanto, é preciso atentar para o fato de que o Goethe de Weimar não simplesmente reedita a arte antiga, mas sua obra dá mostras do surgimento de uma nova objetividade, entendida como a síntese do moderno e do clássico, isto é, uma objetividade mediada pelos elementos subjetivos próprios à arte moderna.

\title{
A crítica de Lukács ao Romantismo: "Havia algo de doentio na coisa toda"
}

Se, como vimos, para os românticos a organicidade da cultura grega afigura-se como uma meta a ser alcançada pela modernidade, é preciso compreender o papel que compete à época clássica na Teoria do romance. Nela, a construção históricofilosófica de Lukács demora-se na caracterização da época moderna: sublinha a perda da totalidade, marca a cisão entre mundo e sentido e denuncia a impossibilidade de se superar essa condição e alcançar um ideal de harmonia e organicidade. A caracterização da época grega serve muito mais como um recurso contrastivo para delinear os contornos da modernidade e, inclusive, Lukács empenha-se por mostrar como a própria cultura grega é completamente harmônica apenas num período 
preciso, o da era homérica, pois a tragédia e a filosofia já testemunham o processo de evasão da substância rumo à transcendência.

Nesse sentido, é possível perceber que aquela oposição entre a naturalidade da cultura grega e a artificialidade da cultura moderna, presente em Schlegel, reaparece no argumento de Lukács, mas agora em uma perspectiva mais atenta aos seus fundamentos sociais. Além da alusão à ideia weberiana da racionalização das ordens de vida, é possível deslindar da contraposição entre os "dois mundos da épica", mundo clássico e mundo moderno, uma referência ao processo econômico e social de passagem de uma organização comunitária da vida para uma estruturação propriamente social, cuja consequência mais interessante para a economia do argumento de Lukács é o surgimento de uma nova relação entre o indivíduo e seu mundo. No mundo clássico, estruturado por laços orgânicos de pertencimento, não há nenhuma distância entre o homem e os valores de sua comunidade, que se thes apresentam como algo natural e incontornável, chancelados pela durabilidade e pela tradição. Rompido o sentido de completude e unidade entre os homens e o mundo, antes assegurado pela magia, pela natureza, pela tradição ou pela religião, a relação entre o homem e o mundo passa a ser marcada pelo signo da cisão: a naturalidade anterior é suplantada pela mediação reflexiva que se interpõe não somente entre o sujeito e o mundo, mas também entre o sujeito e seus próprios atos. Se antes estes possuíam um sentido público, e sustentavam-se em uma moralidade comunitária, no mundo moderno eles estão baseados em uma motivação interna, orientam-se por uma ética individual.

Lukács não deixa de reconhecer que, se esse alargamento dos horizontes do mundo moderno implica na perda de um sentido positivo para a vida, ele ao mesmo tempo significa uma existência mais rica, plural e, no limite, abre espaço para o surgimento da subjetividade. ${ }^{11}$ Por isso a referência à filosofia de Kant, pois sua virada à subjetividade, o tão famoso "giro copernicano", seria o índice de tal transformação. Ademais, se entendermos a filosofia kantiana como a primeira autoexposição filosófica da modernidade, quer dizer, como expressão, no âmbito filosófico, das complexas mudanças culturais e sociais que constituem a modernidade, então parece plausível localizar na Revolução Francesa o marco temporal da modernidade na Teoria do romance. No mundo pós-revolução, em que o indivíduo encontra-se desprovido de uma relação imediata com o sentido do mundo, e nem pode acessar esse sentido por meio de uma instância tradicional ou divina, cabe à razão humana estabelecer sua própria validade como o terreno da busca pela verdade. Por isso, se de um lado a liberdade frente à tradição e aos dogmas religiosos conquistada pela Revolução Francesa significou um avanço no sentido de uma maior autonomia individual, de

11 " 0 círculo em que vivem metafisicamente os gregos é menor do que o nosso: eis por que jamais seríamos capazes de nos imaginar nele com vida; ou melhor, o círculo cuja completude constitui a essência transcendental de suas vidas rompeu-se para nós; não podemos mais respirar num mundo fechado" (Lukács, 2000, p.30). 
outro, essa mesma liberdade é fonte de inquietação, uma vez que a busca por um sentido do mundo passa a ser uma incumbência individual: ao homem solitário, abandonado pelos deuses, resta apenas orientar-se por sua própria razão, para a qual, no entanto, é impossível garantir que não permaneça mera projeção subjetiva, sem relação com o mundo. ${ }^{12}$

O céu estrelado de Kant brilha agora somente na noite escura do puro conhecimento e não ilumina mais os caminhos de nenhum dos peregrinos solitários - e no Novo Mundo, ser homem significa ser solitário. E a luz interna não fornece mais do que ao passo seguinte a evidência - ou a aparência - de segurança. De dentro já não irradia mais nenhuma luz sobre o mundo dos acontecimentos e sobre o seu emaranhado alheio à alma. E quem poderá saber se a adequação do ato à essência do sujeito, o único ponto de referência que restou, atinge realmente a substância, uma vez que o sujeito se tornou uma aparência, um objeto para si mesmo (Lukács, 2000, p.34).

Trata-se, no fundo, de apontar para o processo de individuação e de surgimento da subjetividade o que, por sua vez, desautoriza qualquer pretensão de retorno a uma civilização fundada em um sentido unitário para a vida, como Lukács deixa evidente ao apontar que a ruptura da unidade das esferas da vida é um processo inexorável. Apenas por um breve período, diz ele, na baixa Idade Média, foi possível sonhar com uma nova unidade, já que o cristianismo procurou fazer do mundo novamente uma totalidade fechada, a partir de um sentido manifesto não na existência terrena, mas no mundo do pós-vida. A referência literária nesse momento é a Divina comédia de Dante, que no esquema de Lukács corresponde à transição literária da epopeia para o romance.

Após o rompimento da unidade das esferas, contudo,

qualquer ressurreição do helenismo é uma hipóstase mais ou menos consciente da estética em pura metafísica: um violar e um desejo de aniquilar a essência de tudo que é exterior à arte, uma tentativa de esquecer que a arte é somente uma esfera entre muitas, que ela tem, como pressupostos de sua existência e conscientização, o esfacelamento e a insuficiência do mundo (idem. p.36).

Embora a abordagem de Lukács pareça à primeira vista um tanto etérea seja por seu arcabouço conceitual, seja pela preferência por formulações um tanto abstratas - parece possível afirmar, como já o fizemos, que seu argumento sustenta-se em uma explicação essencialmente social no que diz respeito à ruptura entre a arte grega e a arte moderna, qual seja, a passagem de uma cultura fechada a uma cultura problemática, da comunidade à sociedade, do homem enquanto ser organicamente integrado ao mundo, ao indivíduo mecanicamente relacionado à sociedade. Há uma

12 Como nota Andrew Bowie, o foco da filosofia kantiana na subjetividade está relacionado às mudanças complexas e contraditórias trazidas pela modernidade: "a rápida expansão do capitalismo, a emergência do individualismo moderno, o crescente sucesso do método científico em manipular a natureza para fins humanos, o declínio das autoridades tradicional e teologicamente legitimadas, e a aparição, conjuntamente com a estética enquanto um ramo da filosofia, da 'autonomia estética', a ideia de que obras de arte envolvem regras produzidas livremente, que não se aplicam a nenhum outro objeto natural ou produto humano" (Bowie, 2003, p.2). 
mudança social - nos termos de Lukács, uma transformação na estrutura dos loci transcendentais, isto é, na relação entre vida e substância - irreparável que ocasiona uma ruptura entre a arte dos antigos e arte dos modernos, a ponto desta não poder mais recorrer às formas clássicas na tentativa de solucionar seus problemas.

Quando se fala dos gregos, mistura-se sempre filosofia da história e estética, filosofia e metafísica, e trama-se uma relação entre as suas formas e a nossa era. Belas almas buscam os seus próprios instantes sublimes, instantes fugazmente efêmeros, nunca apreensíveis, de uma sonhada tranquilidade por trás dessas máscaras taciturnas, caladas para sempre, esquecendo que o valor desses instantes é sua fugacidade, que aquilo de que fogem para buscar abrigo junto aos gregos é a sua própria profundidade e grandeza. Espíritos mais profundos, empenhados em coagular em aço purpúreo o sangue que lhes brota e forjá-lo em couraça, para que suas feridas permaneçam eternamente ocultas e seus gestos de heroísmo tornem-se o paradigma do verdadeiro e futuro heroísmo, a fim de que o novo heroísmo seja por ele desperto, comparam a fragmentariedade de sua figuração [Formung] com a harmonia grega, e os próprios sofrimentos, de que brotaram suas formas, com os sonhados martírios que precisaram da pureza grega para ser pacificados (idem, p.28).

Ao criticar as tentativas de salvar a arte moderna seja por meio de um retorno à arte grega, como no caso do classicismo, seja por meio da superação da cisão da cultura moderna em uma síntese futura entre antiguidade e modernidade, como gostaria o romantismo, Lukács atenta para o fato incontornável de que a modernidade é uma época cindida e, como tal, oposta à organicidade que caracteriza a cultura grega, que não é posta por ele nem como ideal a ser recuperado, nem como meta a ser alcançada. Lukács insiste na essência problemática da modernidade já que a toma como algo objetivo, o resultado de um processo histórico que, apesar da abordagem mais conceitual e abstrata do ensaio, sabemos ser no fundo o processo de consolidação da ordem burguesa e do capitalismo.

Isso não significa que a perspectiva de Lukács seja trágica, no sentido de conceber a fragmentação moderna como um conflito insuperável; ${ }^{13}$ antes, essa questão adquire certa ambiguidade ao longo do livro, conforme atesta a segunda

13 Para Löwy, a especificidade do anticapitalismo romântico em sua versão dos anos 1880-1918, frente à ideologia romântica do século XVIII, era seu "espírito de resignação". Os sociólogos alemães, dentre eles Tönnies, Weber e Simmel, que compõem o que Löwy chama de tendência conservadora modernista (em oposição à ortodoxia reacionária), reconheciam o desenvolvimento capitalista como um processo inexorável. Desse modo, a oposição entre a Kultur, esfera que abrange valores éticos, estéticos e políticos, um estilo de vida pessoal, um universo espiritual "orgânico", "natural" e "interior", tipicamente alemão, e a Zivilisation, o progresso material, técnico-econômico, "exterior", "mecânico", "artificial", de origem anglo-saxã, se torna nesses autores um conflito trágico, em que pese a manutenção de certo tom nostálgico quanto ao passado comunitário. 0 próprio Löwy, entretanto, chama a atenção para a posição peculiar de Lukács quanto a essa problemática, pois sua recusa ao capitalismo seria muito mais extrema do que a desses autores, já que estaria fundamentada menos em uma nostalgia pelo passado e mais em uma crítica cultural do capitalismo. Segundo Márkus, em carta citada por Löwy, "Lukács nunca se reconciliou, mesmo durante esse período (antes de 1918), com a visão trágica de mundo a que havia chegado; a autossatisfação e o contentamento mais ou menos cínico de Simmel nunca o caracterizaram; ele sempre tentou - em vão - novos caminhos para abandonar esse trágico dualismo... Há uma impossibilidade pessoal (crescente com os anos) em aceitar como definitivo 0 veredito non possumus" (Löwy, 1998, pp.120-121). 
parte do ensaio, em especial as análises sobre os romances de Goethe, Tolstói e Dostoiévski, na qual a possibilidade de algum tipo de nova cultura no futuro é aventada. O importante é que o fato de sua abordagem estar ancorada na percepção de que a falta de um sentido unitário para o mundo moderno decorre de um processo histórico-social tem como corolário a recusa de uma solução exclusivamente estética para esse problema. O teor dessa divergência de Lukács com o romantismo alemão é explicitado em um ensaio de $A$ alma e as formas intitulado "A filosofia romântica da vida". Nesse texto, Lukács aborda o romantismo de lena e discute seu projeto de criar uma nova cultura, uma comunidade e uma religião cujo centro e elemento motor seria a poesia.

Lukács compreende o romantismo como sendo dotado de um caráter paradoxal. Por um lado, ele parece reconhecer na crítica do romantismo à nascente civilização moderna uma primeira formulação de suas próprias inquietações, relativas à possibilidade de se viver uma vida significativa em um mundo cada vez mais dominado por tendências prosaicas. De fato, vivendo em um momento histórico de choque entre os modos tradicionais de vida e as novas formas de vida burguesa, os pensadores românticos puderam entrever as consequências nefastas que o aprofundamento do modo de vida capitalista traria aos indivíduos, sob a forma de uma sociedade enrijecida, cada vez mais alheia à vontade dos sujeitos. No entanto, apesar de perseverar em temas caros à crítica cultural romântica, Lukács problematiza as soluções aventadas pelo romantismo para superar a condição moderna. Seria mesmo possível poetizar inteiramente o mundo, retornar a uma situação de harmonia na qual a vida e a essência estariam completamente reconciliadas, sem que para isso fosse necessário algum grau de renúncia, de limitação das expectativas frente à realidade?

Lukács nota como o romantismo se vale da imagem harmônica da cultura grega e da Idade Média “como símbolos provisórios para esse novo anseio" de superar a fragmentariedade e a cisão do mundo moderno, de modo que não se trata de uma valorização literal de épocas passadas, mas de uma espécie de símbolo de uma unidade ainda não conquistada, localizada no futuro: "é o antigo sonho de uma era dourada. Mas sua era dourada não é um refúgio em um passado perdido para sempre, para ser apenas vislumbrado de tempos em tempos em velhas lendas maravilhosas é uma meta que é dever de todos alcançar” (Lukács, 2010a, p.65). Se existe algum momento de verdade no romantismo, este residiria, para Lukács, em seu caráter utópico contido na exposição da insuficiência do mundo moderno e na promessa de outro mundo no qual os homens pudessem viver uma vida verdadeira - mais do que uma força regressiva, portanto, Lukács vislumbra no romantismo uma energia utópica.

Entretanto, "havia algo de doentio na coisa toda”, para usar citação recorrente que funciona como uma espécie de mote do ensaio de Lukács. O problema é que a 
ideia de poetizar o mundo, formulada pelos românticos, teria como contrapartida o ato de retirar-se da vida, um refúgio na interioridade que levaria a uma passividade frente ao mundo real. Essa postura, Lukács a reconhece como sendo um problema tipicamente alemão: a via interior, a revolução do espírito, seria a única concebível em um país no qual as condições objetivas não eram as mais favoráveis para que se pensasse seriamente em uma revolução real. Em oposição à postura goetheana de ação no mundo, simbolizada no romance Os anos de aprendizado de Wilhelm Meister, os românticos limitavam-se a esfera do pensamento:

tudo aquilo que neles permanecia método e tendência, tornava-se ato em Goethe; eles não podiam apresentar nada além de meditações problemáticas a respeito da necessidade de superar sua própria problemática, enquanto ele superava a sua; eles procuravam criar um mundo novo onde o grande homem, seu poeta, teria encontrado sua pátria, enquanto Goethe encontrava a sua na vida presente (idem, p.64).

Para o romantismo, tudo se passaria como se a poesia fosse o centro do mundo, pois só ela pode ultrapassar todas as contradições, realizar a síntese da universalidade e da unidade. A realidade efetiva da vida dá lugar a uma outra realidade, poética e puramente espiritual; eles criaram um mundo orgânico e harmonioso e o identificaram ao mundo real e todo e qualquer acontecimento passou então a ter significado, ser necessário. Com isso, diz Lukács, perdeu-se a tensão que existe entre poesia e vida "que dá a uma e a outra suas forças reais e criadoras de valores" (idem, p.67).

A crítica de Lukács, isso deve ficar claro, não se dirige à centralidade conferida pelo romantismo à arte, mas à falta de clareza quanto a seus limites. Apesar destes, é lícito afirmar que a arte continua sendo um lugar de manifestação da verdade para o jovem Lukács: basta pensar que na Teoria do romance ele elege como objeto de estudo justamente essa forma artística - a qual os românticos concebiam como a forma mais representativa da modernidade - e a partir dela procura elaborar uma crítica desta época que, em alguma medida, continua a ser a nossa.

\section{Referências}

Armogathe, J.-R. (2001). «Un ancienne querelle». In: La Querelle des Anciens et des Modernes. Paris: Gallimard, pp. 801-849.

Benjamin, W. (1994). "O Narrador. Considerações sobre a obra de Nikolai Leskov". In: Magia e técnica, arte e política - ensaios sobre literatura e história da cultura. São Paulo: Editora Brasiliense, pp. 197-221.

Bowie, A. (2003). "Introduction". In: Aesthetics and subjectivity: from Kant to Nietzsche. Manchester, UK; New York: Manchester University Press, pp. 1-17.

D’Angelo, P. (1998). A estética do romantismo. Lisboa: Estampa.

Fumaroli, M. (2001). « Les abeilles et les araignées ». In: La Querelle des Anciens et des Modernes. Paris: Gallimard, pp. 7-220.

Habermas, J. (2002). "A consciência de tempo da modernidade e sua necessidade de autocertificação". In: 0 discurso filosófico da modernidade. São Paulo: Martins Fontes, pp. 3-18. 
Hegel, G. W. F. (1999). Curso de estética: o sistema das artes. São Paulo: EDUSP.

Lacoue-Labarthe, P.; Nancy, J-L. (1988). The literary absolute: the theory of literature in German romanticism. Albany: State University of New York Press.

Löwy, M. (1998). A Evolução Política de Lukács: 1909-1929. São Paulo: Cortez.

Lukács, G. (2000). A teoria do romance: um ensaio histórico-filosófico sobre as formas da grande épica. Tradução de José Marcos Mariani de Macedo. $2^{a}$ ed. São Paulo: Duas Cidades/Editora 34.

Lukács, G. (2010a). “On the romantic philosophy of life”. In: Soul and form. New York: Columbia University Press, pp. 59-72.

Lukács, G. (2010b). “The metaphysics of tragedy”. In: Soul and form. New York: Columbia University Press, pp. 175-198.

Nisbet, H. B. (1985). “Introduction”. In: German aesthetic and literary criticism. Cambridge: Cambridge University Press.

Pierucci, A. F. (2003) O desencantamento do mundo: todos os passos do conceito em Max Weber. São Paulo: Editora 34.

Reed, T. J.; Pasley, M. (1982). “The Goethezeit and its aftermath”. In: Germany, a companion to German studies. 2a ed. New York; London: Methuen, pp. 499-558.

Schlegel, F. (1996). Sobre el estudio de la poesía griega. Torrejón de Ardoz: Akal.

Schmidt, R. L. (2011). “Arabesques and the Modern Novel: Friedrich Schlegel's Interpretation of Don Quixote". In: Forms of modernity: Dom Quixote and modern theories of the novel. Toronto: University of Toronto Press, pp. 47-81.

Silva, A. A. (2011). O interessante em Friedrich Schlegel. Trans/Form/Ação, 34, pp. 75-94. DOI: 10.1590/S0101-31732011000400006.

Süssekind, P. (2008). A Grécia de Winckelmann. Kriterion: Revista de Filosofia, 49(117), pp. 67-77. DOI: 10.1590/S0100-512X2008000100004

Szondi, P. (1975a). «Friedrich Schlegel et l'ironie romantique ». In: Poésie et poétique de l'idéalisme allemand. Paris: Les editions de Minuit.

Szondi, P. (1975b). «Le naïf est le sentimental ». In: Poésie et poétique de l'idéalisme allemand. Paris: Editions de Minuit.

Szondi, P. (1992). Poética y filosofía de la historia. Madrid: Visor.

Szondi, P. (2005). Poética y filosofía de la historia. v. 2. Madrid: Visor.

Winckelmann, J. J. (1954). Réflexions sur l'imitation des oeuvres grecques en peinture et en sculpture. Paris: Aubier. 